\title{
Tropospheric methanol observations from space: retrieval evaluation and constraints on the seasonality of biogenic emissions
}

\author{
K. C. Wells ${ }^{1}$, D. B. Millet ${ }^{1}$, L. Hu ${ }^{1}$, K. E. Cady-Pereira ${ }^{2}$, Y. Xiao ${ }^{2}$, M. W. Shephard ${ }^{3}{ }^{*}$, C. L. Clerbaux ${ }^{4,5}$, L. Clarisse ${ }^{5}$, \\ P.-F. Coheur ${ }^{5}$, E. C. Apel ${ }^{6}$, J. de Gouw ${ }^{7,8}$, C. Warneke ${ }^{7,8}$, H. B. Singh ${ }^{9}$, A. H. Goldstein ${ }^{10}$, and B. C. Sive ${ }^{11}$ \\ ${ }^{1}$ Department of Soil, Water and Climate, University of Minnesota, St. Paul, Minnesota, USA \\ ${ }^{2}$ Atmospheric and Environmental Research, Inc., Lexington, Massachusetts, USA \\ ${ }^{3}$ Environment Canada, Downsview, Ontario, Canada \\ ${ }^{4}$ UMPC Univ. Paris 06, Université Versailles St-Quentin, CNRS/INSU, LATMOS-IPSL, Paris, France \\ ${ }^{5}$ Spectroscopie de l'Atmosphère, Service de Chimie Quantique et Photophysique, Université Libre de Bruxelles, Brussels, \\ Belgium \\ ${ }^{6}$ Atmospheric Chemistry Division, NCAR, Boulder, Colorado, USA \\ ${ }^{7}$ Earth System Research Laboratory, NOAA, Boulder, Colorado, USA \\ ${ }^{8}$ CIRES, University of Colorado, Boulder, Colorado, USA \\ ${ }^{9}$ NASA Ames Research Center, Moffett Field, California, USA \\ ${ }^{10}$ Departments of Environmental Science, Policy, and Management and of Civil and Environmental Engineering, UC \\ Berkeley, Berkeley, California, USA \\ ${ }^{11}$ Department of Chemistry, Appalachian State University, Boone, North Carolina, USA \\ * presently at: Atmospheric and Climate Applications (ACApps), Inc., East Gwillimbury, Ontario, Canada
}

Correspondence to: D. B. Millet (dbm@umn.edu)

Received: 16 December 2011 - Published in Atmos. Chem. Phys. Discuss.: 3 February 2012

Revised: 12 June 2012 - Accepted: 13 June 2012 - Published: 12 July 2012

\begin{abstract}
Methanol retrievals from nadir-viewing spacebased sensors offer powerful new information for quantifying methanol emissions on a global scale. Here we apply an ensemble of aircraft observations over North America to evaluate new methanol measurements from the Tropospheric Emission Spectrometer (TES) on the Aura satellite, and combine the TES data with observations from the Infrared Atmospheric Sounding Interferometer (IASI) on the MetOp-A satellite to investigate the seasonality of methanol emissions from northern midlatitude ecosystems. Using the GEOS-Chem chemical transport model as an intercomparison platform, we find that the TES retrieval performs well when the degrees of freedom for signal (DOFS) are above 0.5 , in which case the model:TES regressions are generally consistent with the model:aircraft comparisons. Including retrievals with DOFS below 0.5 degrades the comparisons, as these are excessively influenced by the a priori. The comparisons suggest DOFS $>0.5$ as a minimum threshold for interpreting retrievals of trace gases with a weak tropospheric
\end{abstract}

signal. We analyze one full year of satellite observations and find that GEOS-Chem, driven with MEGANv2.1 biogenic emissions, underestimates observed methanol concentrations throughout the midlatitudes in springtime, with the timing of the seasonal peak in model emissions 1-2 months too late. We attribute this discrepancy to an underestimate of emissions from new leaves in MEGAN, and apply the satellite data to better quantify the seasonal change in methanol emissions for midlatitude ecosystems. The derived parameters (relative emission factors of 11.0, 0.26, 0.12 and 3.0 for new, growing, mature, and old leaves, respectively, plus a leaf area index activity factor of 0.5 for expanding canopies with leaf area index $<1.2$ ) provide a more realistic simulation of seasonal methanol concentrations in midlatitudes on the basis of both the IASI and TES measurements. 


\section{Introduction}

Methanol $\left(\mathrm{CH}_{3} \mathrm{OH}\right)$ is the most abundant non-methane volatile organic compound (VOC) in the atmosphere, with a global burden of 3-4 Tg, and is an important precursor of CO, HCHO, and $\mathrm{O}_{3}$ (Tie et al., 2003; Millet et al., 2006; Duncan et al., 2007; Choi et al., 2010; Hu et al., 2011). The major source of atmospheric methanol is terrestrial plants; plants emit methanol primarily during cell growth (Macdonald and Fall, 1993; Nemecek-Marshall et al., 1995; Galbally and Kirstine, 2002; Karl et al., 2003; Harley et al., 2007) and, to a lesser extent, during decay (Warneke et al., 1999; Karl et al., 2005). Because long-term observations of atmospheric methanol are limited, the spatial distribution, strength, and seasonality of these biogenic emissions are not currently well constrained. Here we use aircraft measurements and a global chemical transport model (GEOS-Chem CTM) to evaluate new space-based observations of tropospheric methanol, and interpret the satellite data in terms of their constraints on the seasonality of biogenic methanol emission fluxes.

Current estimates of the total source of methanol to the atmosphere range from 122 to $350 \mathrm{Tg} \mathrm{yr}^{-1}$ (Heikes et al., 2002; Tie et al., 2003; Singh et al., 2004; Jacob et al., 2005; Millet et al., 2008). Along with emissions from terrestrial plants, sources include atmospheric production via methane oxidation (Tyndall et al., 2001), burning of biomass and biofuels (Holzinger et al., 1999; Andreae and Merlet, 2001), and urban/industrial emissions (Holzinger et al., 2001; de Gouw et al., 2005; Hu et al., 2011). Gross emissions from marine biota are estimated to be comparable in magnitude to those from terrestrial plants (Millet et al., 2008); however, oceans are an overall net sink of atmospheric methanol (Heikes et al., 2002; Carpenter et al., 2004; Williams et al., 2004; Millet et al., 2008; Stavrakou et al., 2011). The other major removal mechanism for methanol is photochemical oxidation by $\mathrm{OH}$, with deposition to land surfaces also being significant (Jacob et al., 2005; Karl et al., 2010). Estimates of the atmospheric lifetime of methanol range from 5-12 days (Galbally and Kirstine, 2002; Tie et al., 2003; Jacob et al., 2005).

Recent modeling studies have found that current emission inventories give rise to substantial regional biases in predicted versus measured methanol concentrations. Millet et al. (2008) compared methanol concentrations simulated by GEOS-Chem (using a net primary production (NPP)-based approach for estimating biogenic emissions) to available aircraft and ground-based measurements, and found evidence for a $\sim 50 \%$ overestimate of biogenic methanol emissions in the eastern US and the Amazon from broadleaf trees and crops. More recently, Stavrakou et al. (2011) employed data from the Infrared Atmospheric Sounding Interferometer (IASI) satellite sensor to constrain biogenic and biomass burning emissions of methanol. Using a different biogenic emission scheme (MEGAN) and the IMAGESv2 CTM, they found a similar overestimate of methanol emissions from broadleaf trees in the eastern US, Amazonia, and Indonesia; however, their results also revealed an underestimate of the biogenic source in more arid regions such as central Asia (by up to a factor of five) and the western US (by a factor of two). Hu et al. (2011) compared methanol measurements from a tall tower in the US Upper Midwest to predicted concentrations from GEOS-Chem driven by MEGAN biogenic emissions. The model-measurement comparisons indicated a modest underestimate $(\sim 35 \%)$ of methanol emissions for that region in summer, but also revealed a significant bias in the seasonality of the modeled biogenic source. This biased model seasonality led to an underestimate of the photochemical role for methanol early in the growing season.

New methanol retrievals from nadir-viewing space-borne sensors offer key information for quantifying biogenic methanol sources to the atmosphere and the corresponding impacts on tropospheric chemistry. In this paper, we use aircraft measurements from an ensemble of field campaigns (Intercontinental Transport Experiment-Phase B, INTEXB; Megacity Initiative: Local and Global Research Observations, MILAGRO; the second Texas Air Quality Study, TexAQS-II; Arctic Research of the Composition of the Troposphere from Aircraft and Satellites, ARCTAS; Aerosol, Radiation, and Cloud Processes affecting Arctic Climate, ARCPAC) with the GEOS-Chem CTM to (i) evaluate atmospheric methanol retrievals from the Tropospheric Emission Spectrometer (TES), and (ii) interpret the TES and IASI space-borne observations in terms of the seasonality of biogenic emissions from major plant functional types in midlatitude ecosystems.

\section{Methanol measurements from space}

Atmospheric methanol was first detected from space via solar occultation spectra from the Atmospheric Chemistry Experiment infrared Fourier Transform Spectrometer (ACEFTS), a limb-viewing infrared sounder onboard the SCISAT1 satellite (Bernath et al., 2005). Enhanced concentrations of methanol were retrieved in the upper troposphere/lower stratosphere in the vicinity of biomass burning plumes (Dufour et al., 2006); subsequent analysis of several years of ACE retrievals showed that a majority of the upper tropospheric methanol burden in the Northern Hemisphere is biogenic in origin (Dufour et al., 2007). The ACE measurements provide important data for determining the influence of surface emissions on upper tropospheric composition, but due to lack of sensitivity in the lower atmosphere they provide limited information on the sources themselves.

Two nadir-viewing infrared sounders currently in space provide observations of methanol in the lower troposphere: TES, launched onboard the EOS Aura satellite in July 2004 (Beer et al., 2001), and IASI, launched onboard the MetOpA satellite in October 2006 (Clerbaux et al., 2009). We use data from both of these sensors in this work. 


\subsection{TES methanol retrieval}

TES, onboard EOS Aura in a polar sun-synchronous orbit (equator overpass 1345 local standard time), is an infrared Fourier transform spectrometer with a spectral resolution of $0.06 \mathrm{~cm}^{-1}$ (apodized) and $5 \times 8 \mathrm{~km}^{2}$ footprint at nadir. Profiles of species such as $\mathrm{O}_{3}, \mathrm{CO}_{2}, \mathrm{CH}_{4}, \mathrm{H}_{2} \mathrm{O}$ and $\mathrm{HDO}$ (monodeuterated water vapor) are derived from the nadir measurements as standard products. The TES retrieval uses an optimal estimation approach, allowing the averaging kernels and error estimates to be directly determined as a part of the retrieval (Rodgers, 2000). The first observations of methanol from TES were reported in Beer et al. (2008). These first results showed high concentrations in the Beijing area, and demonstrated the ability of the sensor to detect localized urban methanol enhancements. Xiao et al. (2012) also recently demonstrated the ability of TES to detect methanol enhancements in Mexico City outflow.

The atmospheric methanol abundance is retrieved based on the spectral residuals between the TES measurements and a forward radiative transfer model (Clough et al., 2006) from 1032.32 to $1034.48 \mathrm{~cm}^{-1}$. This spectral range encompasses the $v_{8} \mathrm{C}$-O stretching band, which is the strongest absorption band for methanol. An example TES observation over North America is shown in Fig. 1 (top panel). The data have units of brightness temperature, i.e. the temperature a blackbody would need to achieve to emit radiation at the observed intensity. The second panel shows the difference between the observed spectrum and a modeled spectrum computed assuming a methanol-free atmosphere, while the third panel shows the measurement-model difference after three iterations to optimize the methanol profile in the forward model. The difference between the model spectrum without methanol and that with methanol is shown in the fourth panel, illustrating the brightness temperature signal $(\sim 1 \mathrm{~K})$ for methanol in this example.

A detailed description of the TES retrieval strategy, initial performance, and sensitivity is provided by Cady-Pereira et al. (2012). The a priori methanol profiles in the TES retrievals are based on simulated profiles for the year 2004 from the GEOS-Chem CTM (described in Sect. 3). Four a priori profiles are employed, corresponding to clean marine, enhanced marine, clean continental and enhanced continental scenes. The clean marine profile was obtained by averaging all simulated marine profiles with mixing ratios $\leq 1 \mathrm{ppb}$ below $500 \mathrm{hPa}$, while the clean continental profile was obtained by averaging all simulated continental profiles with surface mixing ratios $\leq 2 \mathrm{ppb}$. The enhanced marine and continental profiles were derived by averaging the model profiles that exceeded these respective thresholds.

The retrieved methanol profile $\hat{\boldsymbol{x}}$ is related to the true profile $x$ by

$\hat{\boldsymbol{x}}=\boldsymbol{x}_{\mathrm{a}}+\mathbf{A}\left(\boldsymbol{x}-\boldsymbol{x}_{\mathrm{a}}\right)$
TES Observations

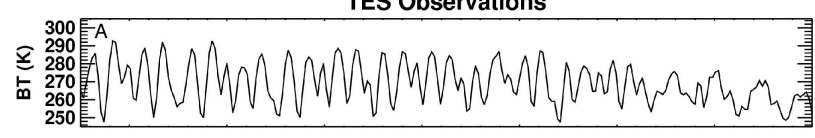

TES Residuals: $\mathrm{No} \mathrm{CH}_{3} \mathrm{OH}$

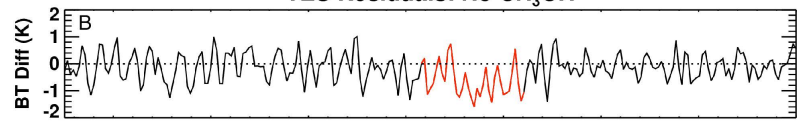

TES Residuals: With Retrieved $\mathrm{CH}_{3} \mathrm{OH}$
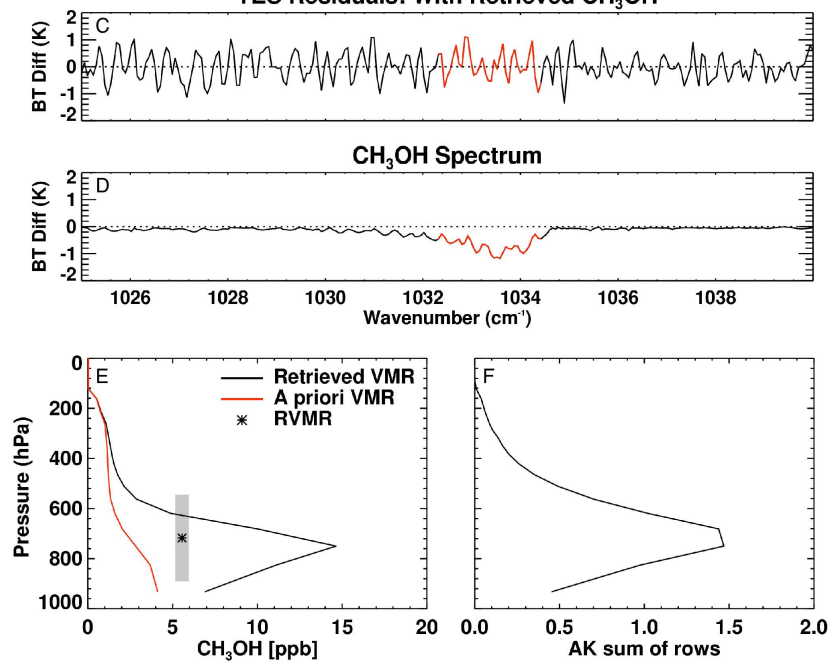

Fig. 1. An example TES methanol retrieval from 7 July 2008 $\left(54.45^{\circ} \mathrm{N}, 113.05^{\circ} \mathrm{W}\right)$. (A) Spectral brightness temperature observed by TES. (B) Residuals between the TES measured spectrum and a modeled spectrum computed assuming a methanol-free atmosphere. (C) Measurement-model residuals after three iterations of the forward model to optimize the methanol profile. (D) Difference between the second and third panels, showing the brightness temperature signal associated with methanol. In each case the spectral range used for the retrieval is shown in red. (E) The corresponding retrieved methanol profile (black line), a priori profile (red line), and the representative volume mixing ratio (RVMR, black symbol) for this example. The shaded bar indicates the vertical range over which the RVMR applies, corresponding to the full width at halfmaximum of the averaging kernel peak. (F) The sum of rows of the averaging kernel for this example.

where $\boldsymbol{x}_{\mathrm{a}}$ is the a priori profile and $\mathbf{A}$ is the averaging kernel matrix. The a priori used in the above example corresponds to an enhanced continental profile, and is shown in the lower left panel of Fig. 1 along with the retrieved profile.

A series of simulated retrievals based on perturbed TES profiles was used to test the performance of the methanol retrieval algorithm. The results, described in detail by CadyPereira et al. (2012), show that the retrieval has low mean bias $(0.16 \mathrm{ppb}$ at $825 \mathrm{hPa})$, with a standard deviation of $0.34 \mathrm{ppb}$. The sum of the rows of the averaging kernel matrix (shown for the above example in the lower right panel of Fig. 1) indicates the fraction of information coming from the measurement versus the a priori. In the example of Fig. 1, we see that peak sensitivity to the atmospheric state occurs 
at $\sim 800 \mathrm{hPa}$. The TES methanol retrievals most commonly exhibit peak sensitivity between $\sim 700$ and $900 \mathrm{hPa}$; above and below this vertical range, most of the information comes from the a priori.

The degrees-of-freedom for signal (DOFS) reflect the information content of the retrieval (i.e. the number of independent variables that can be determined from the measurement), and are calculated as the trace of the averaging kernel matrix. Since the methanol spectral signature in nadir infrared observations is relatively weak (DOFS generally $<1.0$ ), limited information about the true vertical profile can be obtained from the TES measurements. Therefore, in the following analyses we transform the retrieved profile into a single Representative Volume Mixing Ratio, RVMR (Payne et al., 2009; Shephard et al., 2011). The RVMR, $\rho$, provides a measure of the methanol amount at the vertical level(s) where the retrieval is most sensitive.

For methanol, the RVMR is calculated from the retrieved profile as follows:

$\rho=\exp \left[\sum_{i=1}^{n_{\text {levs }}} \log \left(w_{i} \hat{x}_{i}\right)\right]$

where $\hat{x}_{i}$ is the retrieved mixing ratio at level $i$, and $w_{i}$ is the RVMR weighting function at level $i$. The RVMR weighting function is derived from a transformation of the averaging kernel matrix; when the total amount of retrieved information is limited (DOFS $\leq 1.0$ ), as is the case for methanol, it reduces to a vector. The RVMR applies to the pressure range spanned by the full width at half-maximum of the averaging kernel peak, and for the above retrieval example is $5.6 \mathrm{ppb}$ (Fig. 1). RVMR values typically have an uncertainty from 10 to $50 \%$, with the higher relative uncertainties corresponding to smaller RVMR values.

To compare TES retrievals with GEOS-Chem model output, we sample the model at the location and time of the satellite overpass, and apply the corresponding TES a priori profile and averaging kernel using Eq. (1) to derive a model profile as it would be detected by TES. We then calculate the model RVMR based on Eq. (2). For this work, retrievals are performed only for cloud optical depths $<1.0$, and subsequent to the retrieval of surface temperature and emissivity, water vapor, $\mathrm{O}_{3}$, and temperature profiles.

\subsection{IASI methanol retrieval}

IASI, onboard the MetOp-A satellite in a polar sunsynchronous orbit (equator overpass 0930 local standard time), is an infrared Fourier transform spectrometer with a spectral resolution of $0.5 \mathrm{~cm}^{-1}$ (apodized) and a $12 \mathrm{~km}$ footprint diameter at nadir. Given the wide swath $(2200 \mathrm{~km})$ of the instrument's scans, IASI achieves global coverage twice daily, resulting in over 1000000 measured spectra each day. IASI spectra were first used to retrieve methanol in biomass burning plumes (Coheur et al., 2009), and were found to have sufficient temporal and spatial resolution to track the loss of methanol during plume aging.

Retrieval details and global results were recently reported by Razavi et al. (2011). To make use of the high volume of data provided by IASI, the global methanol retrieval uses a fast brightness temperature difference method. In this approach, the difference in brightness temperature between the methanol absorption band $\left(981.25\right.$ to $\left.1038 \mathrm{~cm}^{-1}\right)$ and baseline channels with minimal methanol absorption is calculated, and that difference is converted to a total methanol column using a conversion factor. One oceanic and one continental conversion factor are used; these conversion factors were developed using a subset of full optimal estimation retrievals at select locations around the globe. Average oceanic and continental profiles of methanol from the IMAGESv2 global CTM (Stavrakou et al., 2009, 2011) provide a priori information for the retrieval. Only pixels with $<2 \%$ cloud cover are used. The uncertainty estimate for the retrieved methanol column is $\pm 50 \%$. The mean averaging kernel from the optimal estimation retrievals indicates that IASI's sensitivity to methanol peaks between $\sim 5$ and $10 \mathrm{~km}$ elevation over land.

\section{GEOS-Chem methanol simulation}

We use the GEOS-Chem global 3-D CTM version 8.3.1 (http://www.geos-chem.org) as an intercomparison platform for evaluating the satellite data against aircraft measurements, and to interpret the TES and IASI data in terms of methanol emission processes. GEOS-Chem uses GEOS-5 assimilated meteorological data from the NASA Goddard Earth Observing System, which have a resolution of $0.5^{\circ} \times 0.667^{\circ}$ with 72 vertical levels. We degrade these to a resolution of $2^{\circ} \times 2.5^{\circ}$ with 47 vertical levels for our simulations, and use a one-year spin-up to remove the effect of initial conditions. The sources and sinks of atmospheric methanol are modeled using the simulation described by Millet et al. (2008), with the emission updates described below. Anthropogenic methanol emissions are estimated from those of $\mathrm{CO}$ based on a methanol:CO emission ratio of $0.012 \mathrm{~mol} \mathrm{~mol}^{-1}$ (Goldan et al., 1995; de Gouw et al., 2005; Millet et al., 2005; Warneke et al., 2007). Global anthropogenic CO emissions are from the GEIA inventory (www.geiacenter.org) overwritten with the following regional inventories: EPA/NEI99 emissions over the US (modified to account for recent CO and $\mathrm{NO}_{\mathrm{x}}$ reductions; Hudman et al., 2007; 2008); Streets2006 over Asia (Zhang et al., 2009); BRAVO over Mexico (Kuhns et al., 2003); EMEP over Europe (Vestreng and Klein, 2002; Auvray and Bey, 2005); and NPRI over Canada (http://www.ec.gc.ca/inrp-npri). Biomass burning emissions are derived from the monthly GFEDv2 database (van der Werf et al., 2006) using a methanol:CO emission ratio of $0.018 \mathrm{~mol} \mathrm{~mol}^{-1}$ (Andreae and Merlet, 2001). GFEDv2 
extends through 2008; biomass burning emissions for later years are set to the 2008 values.

Terrestrial biogenic emissions of methanol are computed using the Model of Emissions of Gases and Aerosols from Nature (MEGANv2.1) (Guenther et al., 2006; Stavrakou et al., 2011). Emissions within a GEOS-Chem grid box are estimated as the sum of contributions from five plant functional types (PFTs: broadleaf trees, needleleaf trees, shrubs, grasses, and crops):

$$
E=\gamma \sum_{i=1}^{5} \varepsilon_{i} \chi_{i}
$$

where $\varepsilon_{i}$ is the canopy emission factor at standard conditions for $\mathrm{PFT}_{i}, \chi_{i}$ is the fractional grid box coverage of $\mathrm{PFT}_{i}$, and $\gamma$ is an activity factor used to scale the emissions to local environmental conditions. The total activity factor is derived from individual activity factors for photosynthetically active radiation (PAR), temperature $(T)$, leaf area index (LAI), and leaf age, each equal to 1.0 under standard conditions $\left(\mathrm{PAR}=1500 \mu \mathrm{mol} \mathrm{m}{ }^{-2} \mathrm{~s}^{-1} ; T=303 \mathrm{~K}\right.$; LAI $=5$; leaf age fractions of $0 \%$ new leaves, $10 \%$ growing leaves, $80 \%$ mature leaves, $10 \%$ old leaves). The modeled temperature dependence treats the light-independent fraction (LIF) and light-dependent fraction (LDF) of emissions separately:

$\gamma=\gamma_{\mathrm{age}} \gamma_{\mathrm{LAI}}\left[(1-\mathrm{LDF}) \gamma_{T, \mathrm{LIF}}+(\mathrm{LDF}) \gamma_{\mathrm{PAR}} \gamma_{T, \mathrm{LDF}}\right]$

with $\mathrm{LDF}=0.8$. Light-independent emissions are scaled by $\gamma_{T, \mathrm{LIF}}=\exp (\beta(T-303))$, where $T$ is surface temperature $(\mathrm{K})$ and $\beta$ is the temperature response factor $(0.08)$. For $\gamma_{T, \text { LDF}}$, MEGANv2.1 uses the relationship defined for isoprene (Guenther et al., 2006) with coefficients as reported in Stavrakou et al. (2011). The PAR and LAI activity factors are calculated using the PCEEA algorithm, which is described in Guenther et al. (2006).

Canopy emission factors $\varepsilon_{i}$ are set to $800 \mu \mathrm{g} \mathrm{m}^{-2} \mathrm{~h}^{-1}$ for needleleaf trees, shrubs, crops, and non-tropical broadleaf trees, and $400 \mu \mathrm{g} \mathrm{m}^{-2} \mathrm{~h}^{-1}$ for grasses and tropical broadleaf trees. The fractional coverage of each PFT is based on MEGAN landcover data (PFTv2.0), which is derived from a combination of satellite data, ground survey information, and the Olson et al. (2001) ecosystem database. For local LAI data we use climatological monthly-mean values from MODIS Collection 5 (Yang et al., 2006), which are partitioned into leaf age classes (new, growing, mature, old) using the method outlined in Guenther et al. (2006). The fraction of each leaf age class, $F$, is used to calculate the activity factor for leaf age as:

$\gamma_{\text {age }}=F_{\text {new }} A_{\text {new }}+F_{\text {growing }} A_{\text {growing }}+F_{\text {mature }} A_{\text {mature }}+F_{\text {old }} A_{\text {old }}$

where $A$ is the relative methanol emission rate for each leaf age class. MEGANv2.1 uses relative emission rates of 3.0, 2.6, 0.85, and 1.0 for new, growing, mature, and old leaves, respectively. A key objective of this work will be to derive a more robust constraint on these parameters using satellite data.

We performed global simulations for the years 20062009 to coincide with periods of available in situ and satellite observations (see Sect. 4). The total global methanol source in our simulations is $\sim 200 \mathrm{Tg} \mathrm{yr}^{-1}$. The global terrestrial biogenic methanol source is approximately $\sim 66 \mathrm{Tg} \mathrm{yr}^{-1}$ with little interannual variability (source and sink magnitudes are listed in Table S1 in the Supplement). The biogenic source is lower than the recent optimized estimates of Stavrakou (2011) and Millet (2008) by about $30 \%$. Stavrakou et al. (2011) employed a different canopy model and meteorological fields than used here, while Millet et al. (2008) employed an NPP-based approach (rather than the MEGAN model) to estimate biogenic emissions.

\section{Model-observation comparison over North America}

We use in situ data from recent North American aircraft campaigns to evaluate the space-borne methanol retrievals: MILAGRO (Singh et al., 2009; Kleb et al., 2011) over Mexico, the Gulf of Mexico, and southern Texas (March 2006); INTEX-B (Singh et al., 2009; Kleb et al., 2011) over the Pacific Ocean and western US (April/May 2006); ARCPAC (Brock et al., 2011) over the US (transit flight to Alaska, April 2008); ARCTAS (Jacob et al., 2010) over Canada and the western US (June/July 2008, which comprised the latter phase of the study); and TexAQS-II (Parrish et al., 2009) over the Houston area (September/October 2006). Measurement techniques for each campaign are listed in Table 1, with flight tracks shown in Fig. 2.

As there are few TES observations that coincide precisely in space and time with an aircraft measurement for the campaigns used in this study, we use GEOS-Chem as a transfer standard for comparing the TES retrievals with the aircraft data. We employ TES retrievals that correspond spatially with the aircraft flight tracks and within the timeframe of the various campaigns shown in Fig. 2, and average together all qualifying retrievals within a model grid box for a given hour. We then sample the model at the specific time and location of each retrieval, and apply the corresponding TES RVMR weighting function, a priori profile and averaging kernel matrix to obtain a model RVMR (Eqs. (1) and (2)) for direct comparison with TES. We consider only retrievals with a quality flag equal to 1 , corresponding to a converged retrieval with DOFS $>0.1$. Later we specifically evaluate the importance of DOFS in interpreting the satellite data.

To compare the model output with the aircraft data, we sample the model at the time, location, and pressure of each flight observation, and aggregate the results to the GEOSChem model resolution. We restrict the TES:model and aircraft:model comparisons to gridboxes containing at least one aircraft and one TES observation. The aircraft data include vertical information along the track, resulting in more total 
Table 1. Aircraft measurements of methanol used for evaluation of TES and IASI space-based retrievals ${ }^{1}$.

\begin{tabular}{lll}
\hline Experiment & Dates & Method and reference \\
\hline MILAGRO C130 & March 2006 & In-situ GC, Apel et al. (2003) \\
MILAGRO DC8 & March 2006 & In-situ GC, Singh et al. (2001) \\
INTEX-B C130 & April/May 2006 & In-situ GC, Apel et al. (2003) \\
INTEX-B DC8 & April/May 2006 & In-situ GC, Singh et al. (2001) \\
ARCPAC & April 2008 & PTR-MS, de Gouw and Warneke (2007) \\
ARCTAS (phase 2) & June/July 2008 & In-situ GC, Apel et al. (2003) \\
TexAQS-II & Sept/Oct 2006 & PTR-MS, de Gouw and Warneke (2007) \\
\hline
\end{tabular}

${ }^{1}$ Flight tracks shown in Fig. 2.
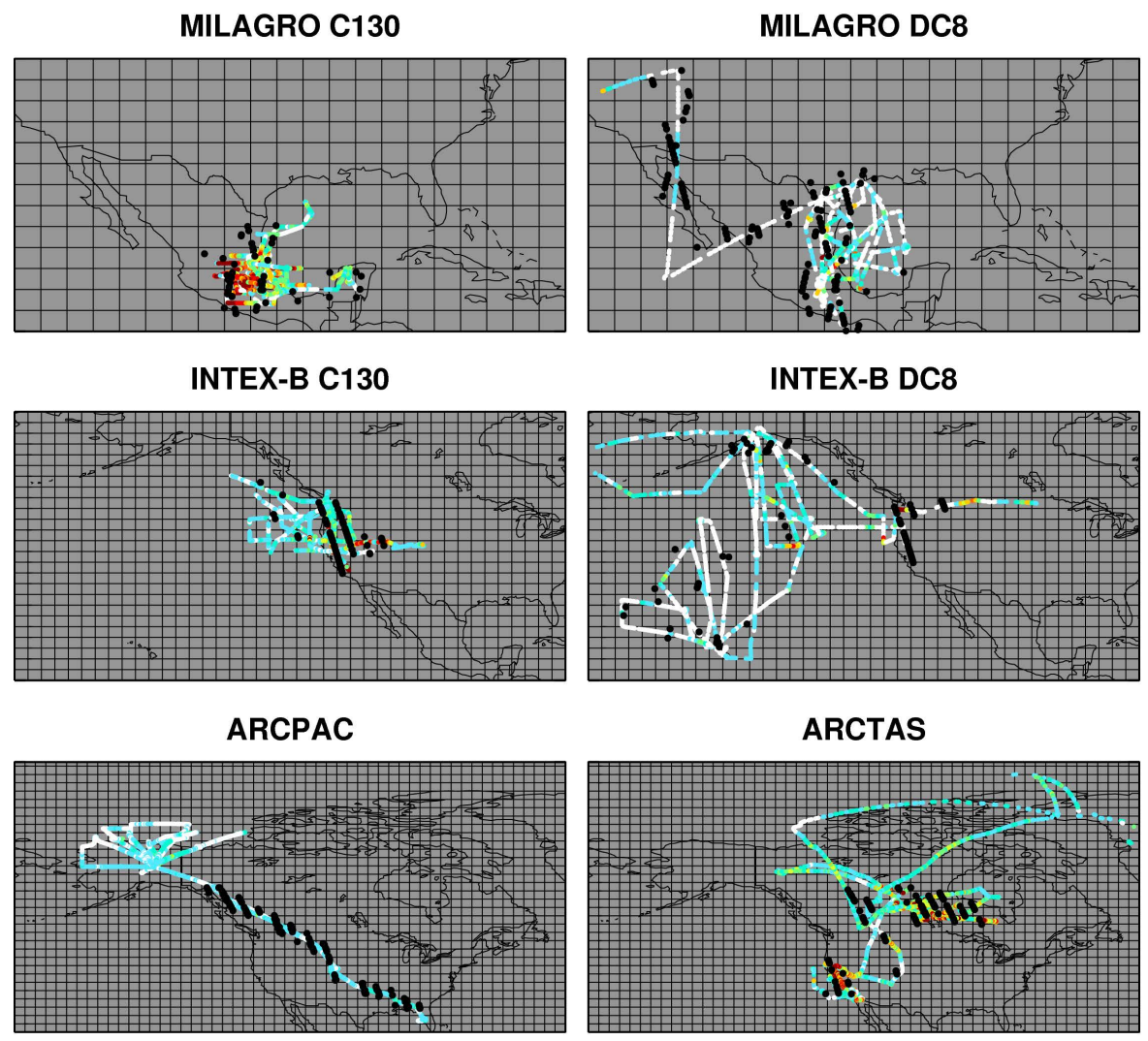

TexAQS-II

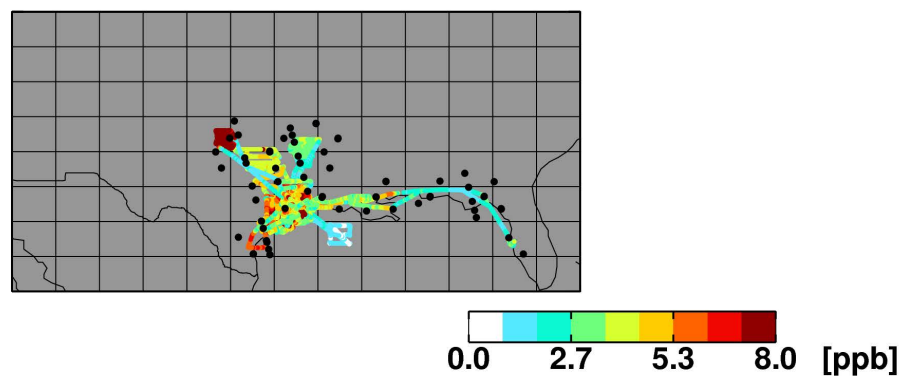

Fig. 2. Maps of aircraft campaign flight tracks and TES observations used for intercomparison. Flight tracks are colored by measured $\mathrm{CH}_{3} \mathrm{OH}$ concentrations and the selected TES observations are shown as black circles. The grid lines indicate the GEOS-Chem grid box boundaries. 
datapoints for the latter comparisons. The TES:model comparisons then provide a measure of the TES data reliability based on the extent to which they are consistent with the corresponding aircraft:model regressions. Figure 2 illustrates the spatial sampling of the TES measurements and flight data employed in these comparisons, along with the GEOS-Chem grid resolution.

We also include IASI column retrievals in the comparison, though the IASI data are from 2009 , so they do not correspond directly to the time period of the in situ observations. In this case, we apply the IASI land and ocean averaging kernels and a priori profiles to the GEOS-Chem output for 2009 at the approximate time of the IASI observations in the same manner as we do for the TES observations (Eq. (1)). We then convert the sampled model profile to a total column value for comparison with IASI. Currently, only a monthly-mean $\left(0.5^{\circ} \times 0.5^{\circ}\right)$ product from IASI is available, so we average the model output over the same time period. We aggregate the IASI data to the GEOS-Chem resolution and restrict the IASI:model comparisons to the same gridboxes that were retained for the TES:model and aircraft:model comparisons.

Results of the satellite-model-aircraft cross-comparisons are shown in Fig. 3 for TES retrievals with DOFS >0.5. Initial analyses revealed that the TES data contain two populations split by a DOFS threshold of $\sim 0.5$. Retrievals with DOFS below 0.5 tend to agree well with the simulated values from GEOS-Chem, falling around the 1:1 line in the comparisons (Fig. S1 in the Supplement). Retrievals with DOFS $>0.5$, on the other hand, though still well-correlated with the model, tend to be higher and with a different slope compared to the model output (Figs. 3, S1 in the Supplement). This bimodal distribution in the TES observations reflects the fact that TES methanol retrievals with DOFS less than 0.5 tend to be significantly influenced by the a priori (and thus fall close to the 1:1 line since the a priori is generated using GEOSChem). This result was also found for the TES ammonia retrieval (Shephard et al., 2011), and suggests a general threshold for information content in retrievals of trace gases with a weak tropospheric signal. Cady-Pereira et al. (2012) discuss this point in greater detail. The IASI data show evidence of a similar bimodal distribution compared to the model (e.g., in the INTEX-B comparisons in Figs. 3 and S1 in the Supplement). However, the IASI methanol data do not provide a direct way to remove this effect, since the brightness temperature retrieval approach does not enable computation of the DOFS for each scene. The fact that TES methanol retrievals with DOFS $>0.5$ are generally higher than the simulated values from GEOS-Chem suggests a source underestimate for the spatial-temporal domain of these comparisons.

For the INTEX-B comparisons in Fig. 3, the TES retrievals are consistent with both the C-130 and DC- 8 airborne measurements. In both cases, the TES:model slope is statistically indistinguishable from the corresponding aircraft:model slope, and the correlation coefficients are also very similar. In the case of MILAGRO, the C-130 data con- tain a pronounced urban influence as sampling was focused over Mexico City; TES exhibits lower concentrations (and a higher correlation with the model) because its orbit did not track directly over Mexico City (Fig. 2). For the DC-8 flight tracks during MILAGRO, neither the TES nor the IASI data are correlated with the model. This campaign focused on sampling Mexico City outflow during transport over the Gulf of Mexico; it may be that the satellite measurements include some plumes that are not captured at the $2^{\circ} \times 2.5^{\circ}$ resolution of GEOS-Chem.

The ARCPAC data are the only instance with an aircraft:model slope near 1, although a 1-2 ppb offset exists between the observations and the model. As this was a transit flight for the campaign with little vertical profiling, the influence of near-field emissions is lower than in the other campaigns. For ARCPAC, most of the TES RVMR values fall in the same range as the aircraft observations, but a few high retrieved concentrations lead to an overall low correlation with the model. Two of these high TES values occurred over the Colorado Front Range near Colorado Springs and Pueblo, and may include urban boundary-layer pollution that was not sampled by the aircraft. The other two occurred over central/eastern Oklahoma and may be influenced by large wildfires that were burning in central Oklahoma during the campaign. For the ARCTAS campaign, the TES:model slope is very similar to the aircraft:model slope, and with a similar degree of correlation. The TES data are low compared to the aircraft data during TexAQS-II, probably because there were few TES observations directly over the urban core during this campaign (Figs. 2 and 3).

The IASI data in Fig. 3 are not strictly analogous to the instantaneous values from the aircraft and TES, since they are total column monthly-average values, but they do provide a picture that is generally consistent with the TES:model comparisons. For those campaigns with a significant IASI-model correlation $(r>0.25)$, the slopes are all above 1.0, supporting a source underestimate in the GEOS-Chem methanol simulation for the domain of these comparisons.

In summary, the satellite:model comparisons appear broadly consistent with the information provided by the aircraft data. The satellite instruments demonstrate fidelity in resolving methanol variability in the atmosphere: correlation coefficients between the satellite and model are for the most part similar to the aircraft:model values, with certain exceptions discussed above. TES:model regression slopes are similar to the aircraft:model slopes, so there is no indication of a persistent bias in the TES data with respect to the aircraft measurements. The IASI data exhibit consistently lower slopes than the TES:model and aircraft:model comparisons; this may be because the IASI sensitivity to methanol peaks higher in the atmosphere than does that of TES (Beer et al., 2008; Razavi et al., 2011), but it may also be partly due to the influence of retrievals with low DOFS that are by necessity retained in the comparison. 

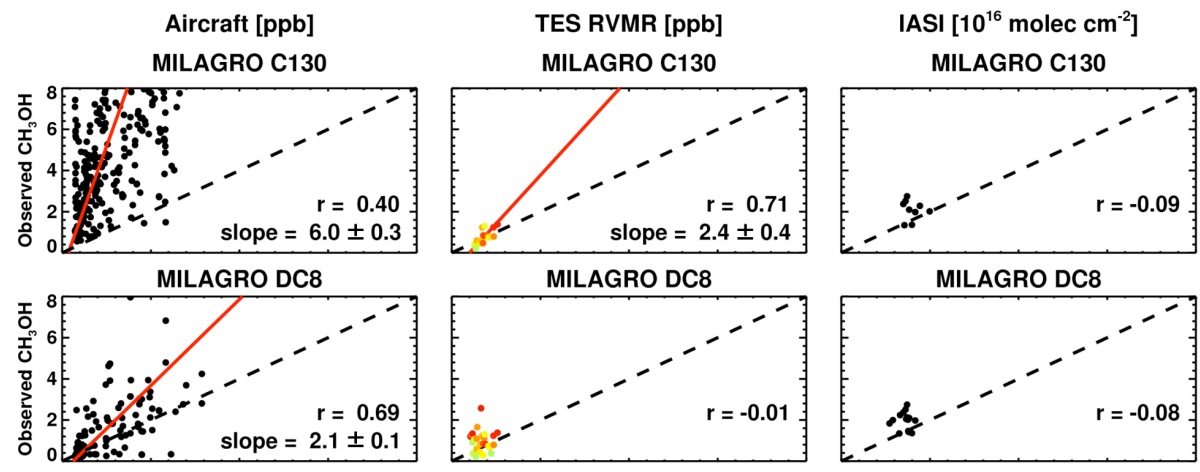

MILAGRO DC8
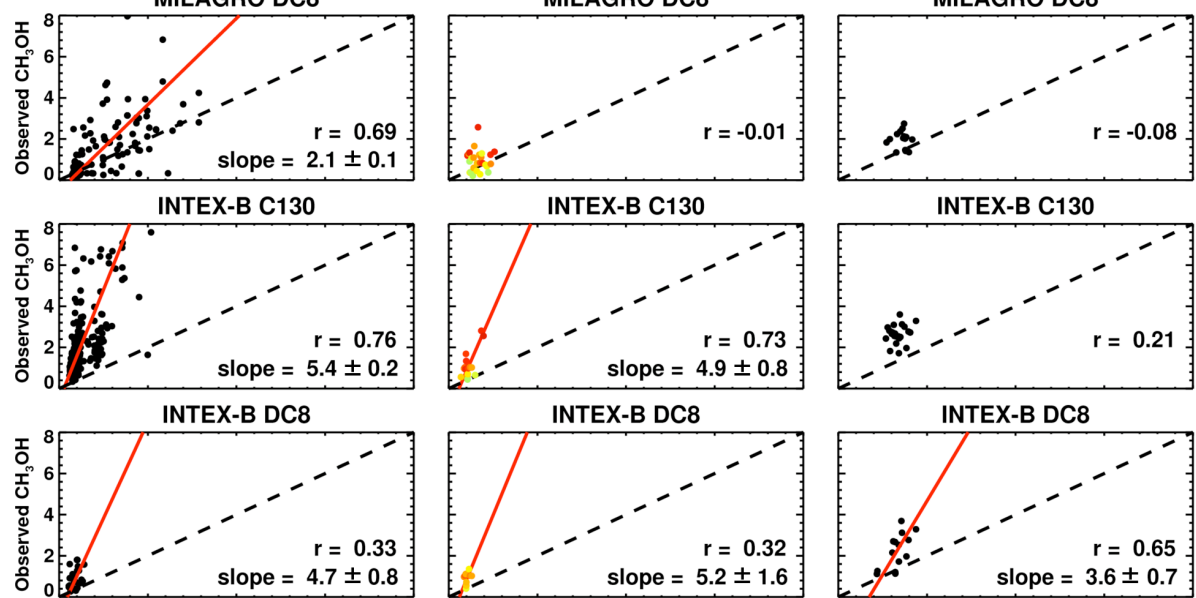

INTEX-B C130
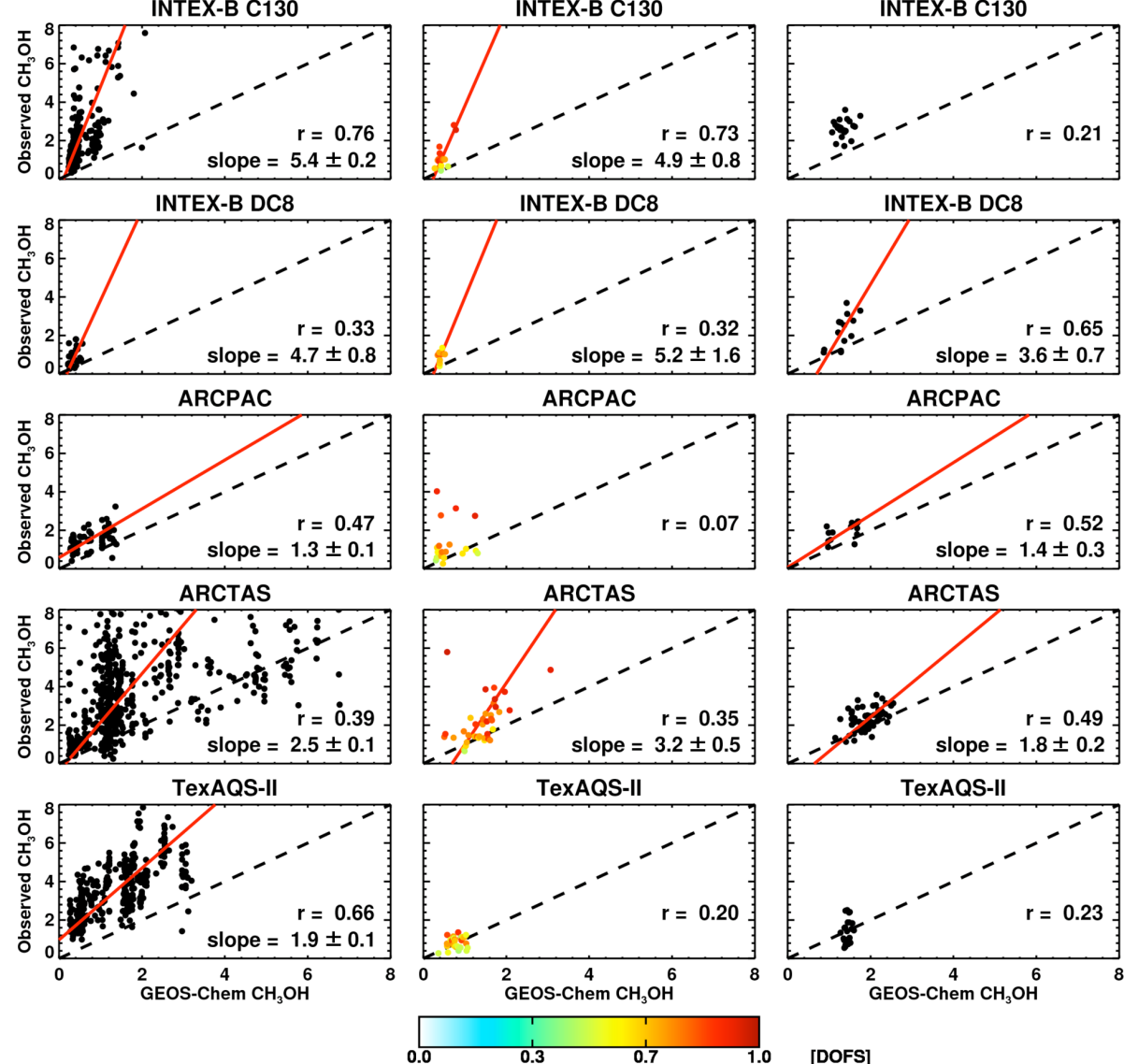

[DOFS]

Fig. 3. Comparison of TES, IASI and airborne methanol measurements using GEOS-Chem as an intercomparison platform. Methanol abundance as modeled by GEOS-Chem (base-case simulation) is compared to aircraft (left column, ppb), TES (middle column, ppb) and IASI (right column, $10^{16}$ molec $\mathrm{cm}^{-2}$ ) measurements for the field campaigns shown in Fig. 2. TES data are colored according to their DOFS, and only DOFS $>0.5$ are shown. Red lines correspond to a reduced major axis fit to the data (only performed for $r>0.25$ ). Uncertainty estimates correspond to the standard error of the regression.

\section{Seasonality of biogenic methanol emissions}

Recent work by $\mathrm{Hu}$ et al. (2011) showed that MEGAN biogenic emissions, implemented in GEOS-Chem, lead to predicted methanol concentrations that are phase-shifted seasonally relative to observations in the US Upper Midwest. The result is an underestimate of the pronounced photochemical role for methanol early in the growing season, a time of year when methanol emissions and concentrations are high, but isoprene emissions are still relatively low. With the exception of TexAQS-II, all aircraft campaign data used in this study were taken during the spring and early summer months over North America, so the apparent model underestimate discussed above may be at least partly attributable to this seasonality bias. In this section we apply the TES and IASI space-borne observations to address this issue, and derive 
new top-down information on the seasonality of biogenic methanol emissions.

\subsection{Methanol emissions as a function of leaf age and plant functional type}

A limited number of laboratory enclosure studies and abovecanopy measurements have been conducted to examine methanol emissions from different plant species at various stages of leaf growth. It is currently understood that plants produce methanol via dimethylation of pectin during cell wall expansion (Galbally and Kirstine, 2002) and thus emit more methanol during their growing period. Hüve et al. (2007) found that emissions were $4 \times$ higher for young versus mature leaves of eastern cottonwood, while NemecekMarshall et al. (1995) found that emission rates decreased by nearly a factor of 20 between the youngest and oldest leaves of the same species. MacDonald and Fall (1993) found that emission rates from fully expanded leaves dropped by $\sim 2$ $10 \times$ from the rates of young leaves. Harley et al. (2007) reported that emissions from young leaves can be at least an order of magnitude higher than those from mature leaves of the same plant. A recent study by Bracho-Nunez et al. (2011) showed that methanol emission rates from young leaves of several Mediterranean plant species were 25-90\% higher than those from the mature leaves. Karl et al. (2003) measured springtime fluxes of methanol that were $1.7 \times$ higher in spring than in fall over a hardwood forest in northern Michigan, and Custer and Schade (2005) found that methanol emissions from a sugar beet field were an order of magnitude higher in the early part of the growing season than in midto-late summer. Taken together, these studies provide clear evidence of enhanced methanol emissions in younger versus older leaves, but the observed variability raises a challenge in terms of implementing the phenomenon in a robust way in global emission models.

\subsection{Application of space- based observations to constrain seasonal emissions}

To better quantify the seasonality of methanol emissions, we compare total column amounts simulated by MEGANv2.1 and GEOS-Chem to those measured by IASI over selected temperate regions of the globe. We use IASI for this comparison because of the sampling statistics provided by its high spatial and temporal resolution, which minimize any influence from random error. We will then employ the TES data, with its higher spectral resolution, as an independent test of the results. We focus our analysis on midlatitude regions of the Northern Hemisphere without significant biomass burning influence. Regions were defined as shown in Fig. S2 in the Supplement: western US, eastern US, southern Canada, Europe, and southern Siberia. The fractional coverage for each of the MEGAN PFTs in these regions is listed in Table 2 , and the total emissions by source for each region are

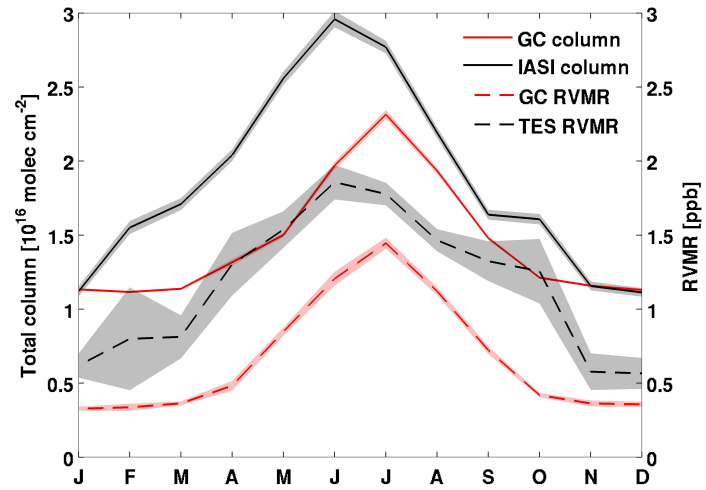

Fig. 4. Seasonal cycle in atmospheric methanol over midlatitudes for 2009. Shown are methanol column amounts simulated by GEOS-Chem (base-case simulation, red solid line) and measured by IASI (black solid line), and representative volume mixing ratios (RVMR) simulated by GEOS-Chem (base-case simulation, red dashed line) and measured by TES (black dashed line). TES RVMR data include only those observations with DOFS $>0.5$. The data represent an average over the northern midlatitude regions of Fig. S2, and shaded areas show the standard error about the mean.

listed in Table S1 in the Supplement. The modeled biogenic source dominates in all of these regions.

Figure 4 shows timelines of methanol abundance as measured by IASI (total column, molec $\mathrm{cm}^{-2}$ ) and TES (RVMR, ppb), and simulated by GEOS-Chem, averaged over the midlatitude regions of Fig. S2 for 2009. As above, we sample the model to account for the vertical sensitivity of each satellite sensor and to minimize any influence from the a priori on the comparisons. Both the TES and IASI ensembles exhibit the same seasonal offset compared to the model as was observed by Hu et al. (2011) over the US Upper Midwest, with the observed seasonal peak occurring one month earlier than in the simulation. The TES and IASI datasets are seasonally in-phase, both showing the largest discrepancy with respect to the model during springtime. Figure 5 shows methanol column timelines for 2009 as measured by IASI and simulated by GEOS-Chem for the five regions that made up the ensemble mean in Fig. 4. The figures also include the individual model contributions from biogenic and other sources. As we see, the biogenic source clearly drives the seasonality of the simulated methanol column in all of these regions, serving as the major source of atmospheric methanol during spring, summer and fall.

The comparisons in Fig. 5 show that the methanol source underestimate in MEGAN+GEOS-Chem occurs predominantly during springtime. It is also especially pronounced in the western US; the GEOS-Chem column amounts would need to be increased by nearly $2 \times$ over this region to match those observed from IASI. Our comparisons above with North American aircraft observations are consistent with these findings. The results point to a misrepresentation of the seasonality of biogenic methanol emissions, as well as 
Table 2. Percent coverage of plant functional types in the MEGAN landcover database for selected midlatitude regions ${ }^{1}$.

\begin{tabular}{lccccc}
\hline Region & \% Broadleaf trees & \% Needleleaf trees & \% Shrubs & \% Grasses & \% Crops \\
\hline W. US & 1.6 & 11.1 & 14.5 & 29.6 & 11.5 \\
E. US & 20.1 & 18.2 & 8.3 & 11.7 & 29.4 \\
S. Canada & 1.6 & 37.4 & 24.9 & 12.0 & 6.9 \\
Europe & 8.5 & 20.1 & 9.7 & 12.1 & 37.0 \\
S. Siberia & 2.4 & 36.8 & 26.8 & 16.0 & 5.2 \\
\hline
\end{tabular}

${ }^{1}$ Region boundaries are shown in Fig. S2.

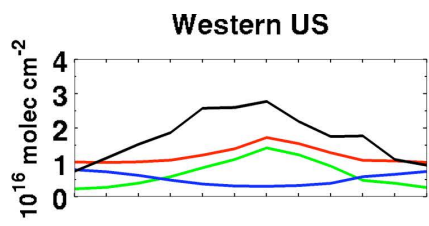

Southern Canada

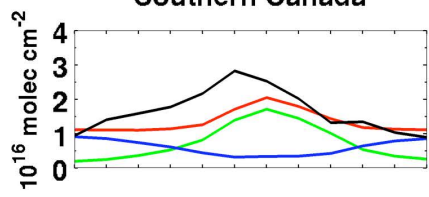

Southern Siberia

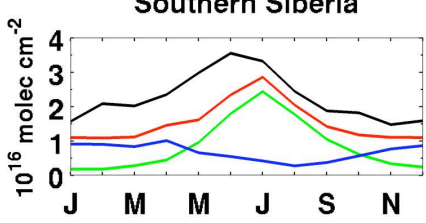

Fig. 5. Seasonal source contributions to atmospheric methanol for the northern midlatitude regions of Fig. S2 in the Supplement: Western US $\left(35-50^{\circ} \mathrm{N}, 120-100^{\circ} \mathrm{W}\right)$, Eastern US $\left(35-50^{\circ} \mathrm{N}, 100-\right.$ $\left.60^{\circ} \mathrm{W}\right)$, Southern Canada $\left(50-60^{\circ} \mathrm{N}, 130-60^{\circ} \mathrm{W}\right)$, Europe $(40-$ $\left.50^{\circ} \mathrm{N}, 0-30^{\circ} \mathrm{E}\right)$, and Southern Siberia $\left(50-65^{\circ} \mathrm{N}, 80-140^{\circ} \mathrm{E}\right)$. Shown are 2009 timelines of the methanol column as measured by IASI (black) and simulated by GEOS-Chem (base-case simulation, red). The individual model contributions from biogenic (green) and all other sources (blue) are also shown. Lines show the mean over each region.

a potential missing source in the western US. Other sources of error that could influence the simulated seasonal cycle include model meteorology and methanol sinks (i.e., dry deposition and $\mathrm{OH}$ oxidation). However, these cannot explain the observed seasonal discrepancy, which is apparent over midlatitude landscapes around the world. Sensitivity runs employing alternate $\mathrm{OH}$ (archived from an earlier model version) and meteorological fields (GEOS-4), and allowing for reactive uptake of methanol (Karl et al., 2010), all result in a negligible change to the seasonal cycles shown in Figs. 4 and 5. We also do not find a seasonal bias in simulated methanol concentrations over oceans, indicating that air-sea exchange does not contribute to the observed seasonal discrepancy over land.

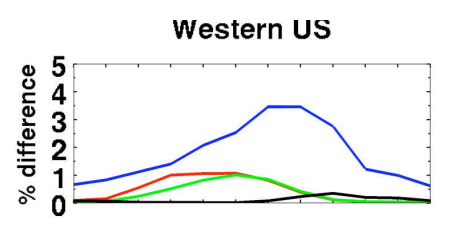

Southern Canada

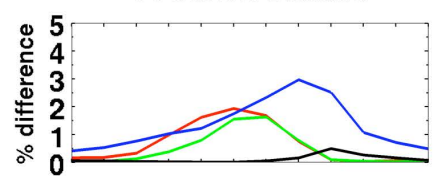

Southern Siberia

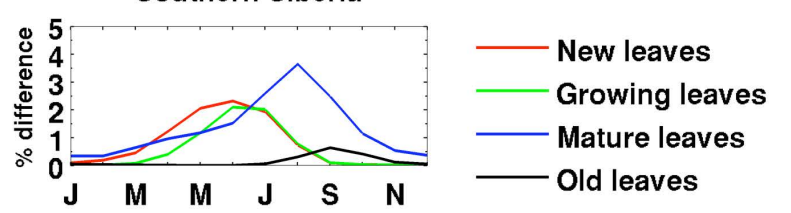

Fig. 6. 2009 timelines of the percent difference in the total column methanol from GEOS-Chem for a $10 \%$ increase in the relative emissions from new leaves (red), growing leaves (green), mature leaves (blue), and old leaves (black) for the five regions considered in this study (Fig. S2). Lines show the mean over each region.

We thus apply the IASI data to derive optimal relative emission rates for the different leaf age categories in terms of reproducing observed seasonal patterns in atmospheric methanol. Four simulations were performed in which the relative emission rates for new, growing, mature, and old leaves were individually increased by $10 \%$. The resulting fractional increases in the simulated methanol column (sampled according to the IASI sensitivity) are shown in Fig. 6 for the five midlatitude regions considered. Increases in the relative emission rates of new and growing leaves manifest as increases in atmospheric methanol during spring, while increases for mature and old leaves are strongest during late summer and fall, respectively. Using these sensitivities, we derive a set of optimized relative emission factors by fitting to an area-weighted mean of the IASI observations over the five regions of interest. The fit is derived using a constrained multivariate linear regression routine, in which the optimized parameters are not permitted to decrease by more than $90 \%$ of their original value. As our focus here is on the seasonality 


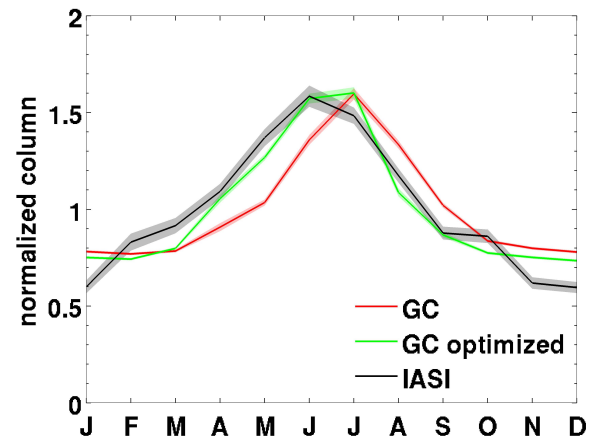

Fig. 7. Seasonal cycle in atmospheric methanol over midlatitudes as measured by IASI (black) and predicted by the GEOS-Chem basecase (red) and optimized (green) simulations. Data are for 2009 and are normalized by the annual mean in each case. Lines show the mean over all midlatitude regions of Fig. S2, while shaded areas indicate the standard error about the mean.

of emissions rather than the absolute amount, we fit the IASI column normalized by its annual mean.

Despite the fact that emissions from new and growing leaves peak during spring (Fig. 6), our initial optimization attempts were unable to close the satellite:model discrepancy at that time of year. Increasing $A_{\text {new }}$ has only a marginal effect on springtime emissions because the increase is damped by low values of $\gamma_{\text {LAI }}$. One reason for the large model bias at this time of year could thus be an underestimate in the MODIS LAI product for new and expanding canopies. It is also possible that additional sources of methanol not currently represented in MEGAN, such as leaf buds, soil emissions (Schade and Custer, 2004), or snowmelt (e.g. Lappalainen et al., 2009), contribute to the early season discrepancy. To address this, we set $\gamma_{\mathrm{LAI}}=0.5$ (corresponding to an LAI of 1.2) when the leaf canopy is expanding, and use the standard PCEEA formulation (Guenther et al., 2006) when the canopy is static or declining. The $\gamma_{\text {LAI }}$ value of 0.5 is able to close the model-measurement gap in the early springtime while not corresponding to an excessively high LAI value.

We then find that revised parameters of $A_{\text {new }}=11.0$, $A_{\text {growing }}=0.26, A_{\text {mature }}=0.12$, and $A_{\text {old }}=3.0$ are able to capture the seasonality observed in the IASI midlatitude methanol measurements. These optimized parameters represent a $\sim 40 \times$ difference in emissions between new and growing leaves, and a $\sim 2 \times$ difference in emissions between growing and mature leaves. As discussed above, methanol emissions have been observed to decrease by an order of magnitude or more between new and mature leaves, so these satellite-derived parameters have some consistency with in situ observations. They do represent a larger decrease than some in situ studies suggest but, as is later shown, these new relative emission factors provide a much more realistic simulation of atmospheric methanol seasonality across midlatitude ecosystems. Emissions from old leaves are increased to match observed column amounts in the fall. This likely re-

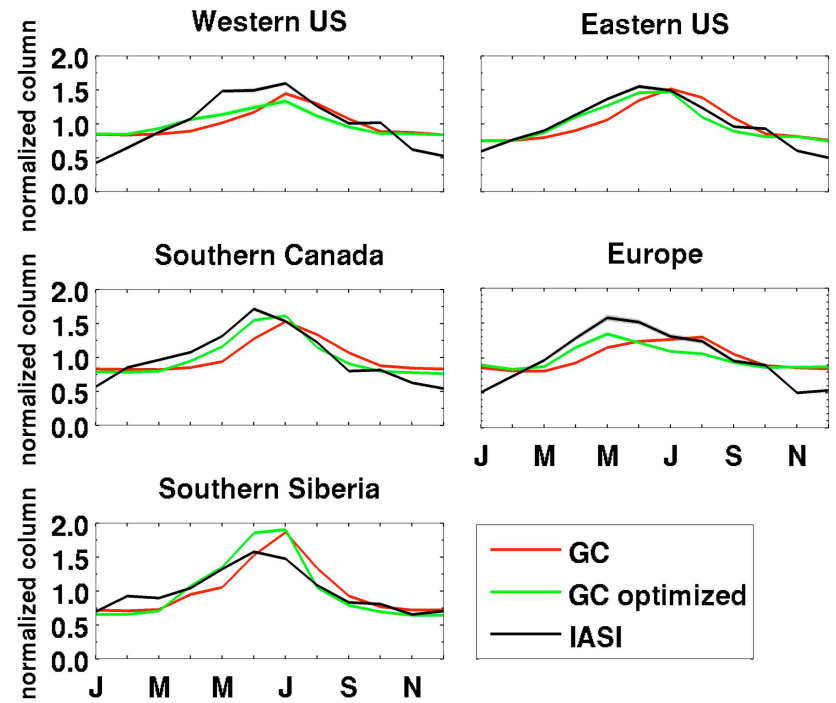

Fig. 8. Seasonal cycle in atmospheric methanol over midlatitude regions as measured by IASI (black) and predicted by the GEOSChem base-case (red) and optimized (green) simulations. Data are for 2009 and are normalized by the annual mean in each case. Lines show the mean for each of the midlatitude regions of Fig. S2.

flects larger emissions from dead and decaying plant material than currently assumed.

The revised relative emission factors do not adhere to the MEGAN convention that $\gamma_{\mathrm{AGE}}=1.0$ under standard conditions (Eq. (5)). Because standard conditions assume $0 \%$ new leaves, we find that forcing the values to fit the $\gamma_{\mathrm{AGE}}=1.0$ criterion leads to artificially high emissions for old leaves, to compensate for the lower emissions from mature and growing leaves. This in turn significantly degrades the fit with respect to observations during fall.

Updated simulation results using the revised leaf age emission factors (and setting $\gamma_{\text {LAI }}=0.5$ when canopies are expanding and $\mathrm{LAI}<1.2$ ) are compared to IASI data in Fig. 7. These modifications shift and broaden the seasonal peak in the simulated methanol column, so that it is more consistent with the observational constraints. As a result, the simulated and observed (normalized) columns agree well from April to September, though observations still indicate an earlier onset in spring emissions than predicted by MEGAN+GEOSChem.

Figure 8 shows methanol column amounts (normalized by the annual mean) for the optimized simulation, standard simulation, and IASI for each of the five regions that compose the midlatitude ensemble. The optimized simulation demonstrates much better fidelity in capturing the observed seasonal pattern over each of these regions. Correlation coefficients between IASI and GEOS-Chem and seasonal root mean square differences (RMSD) are listed in Table S2 in the Supplement. The optimized parameters improve the model correlation with IASI in all of the midlatitude regions, and 


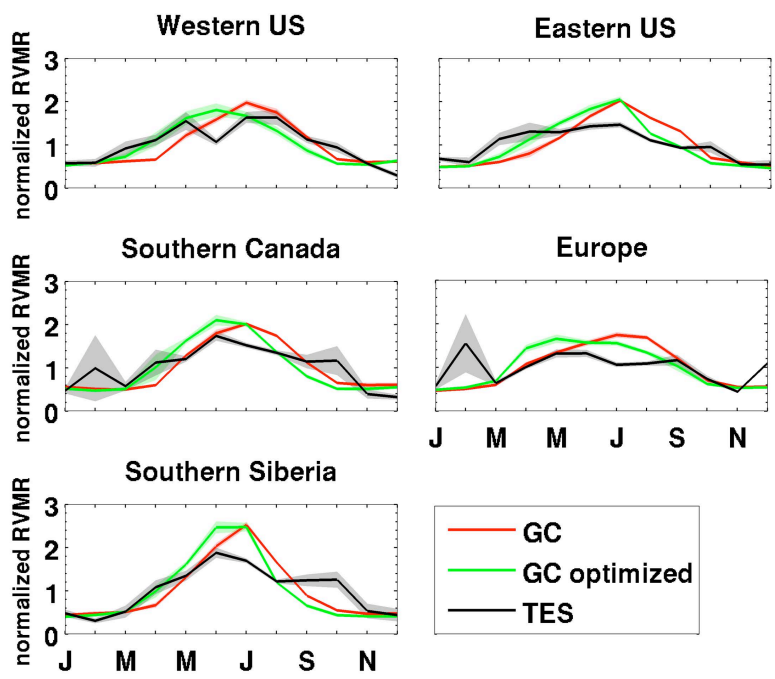

Fig. 9. Seasonal cycle in atmospheric methanol over midlatitude regions as measured by TES (black, for DOFS $>0.5$ ) and predicted by the GEOS-Chem base-case (red) and optimized (green) simulations. Data are for 2009 and are normalized by the annual mean in each case. Lines show the mean for each region (Fig. S2), while shaded areas indicate the standard error about the mean.

reduce the model-measurement difference in the spring. We also examined the effect of the optimized relative emission factors on simulated methanol amounts in the tropics; overall emissions were slightly reduced, and in some areas the seasonal amplitude is now larger than observed. Our revised leaf age emission parameters are therefore recommended for temperate but not for tropical ecosystems.

For some of the cases in Fig. 8, the simulated seasonal amplitude is weaker (e.g., Europe) or stronger (e.g., southern Siberia) than observed, though the phase is accurate. Model-measurement RMSD values in winter and summer are somewhat larger post-optimization in these regions. Such discrepancies indicate a need for improved estimates of absolute methanol emission rates (rather than their seasonal timing) for different plant functional types in the midlatitudes, or possibly for improved estimates of other, non-biogenic, sources of methanol.

Comparisons with independent data from TES provide support for our revised leaf age emission factors. Figure 9 shows TES global survey retrievals for 2009 over the same five midlatitude regions used above. Only retrievals with DOFS $>0.5$ are included. As with IASI, the TES retrievals reveal a late spring/early summer peak in atmospheric methanol over midlatitude ecosystems, which is better captured by the optimized simulation. The model-measurement correlation is improved in the optimized simulation (with the exception of the western US), and the spring modelmeasurement RMS differences are reduced in all regions except Europe. Over all five regions the TES observations exhibit weaker seasonality than MEGAN+GEOS-Chem or
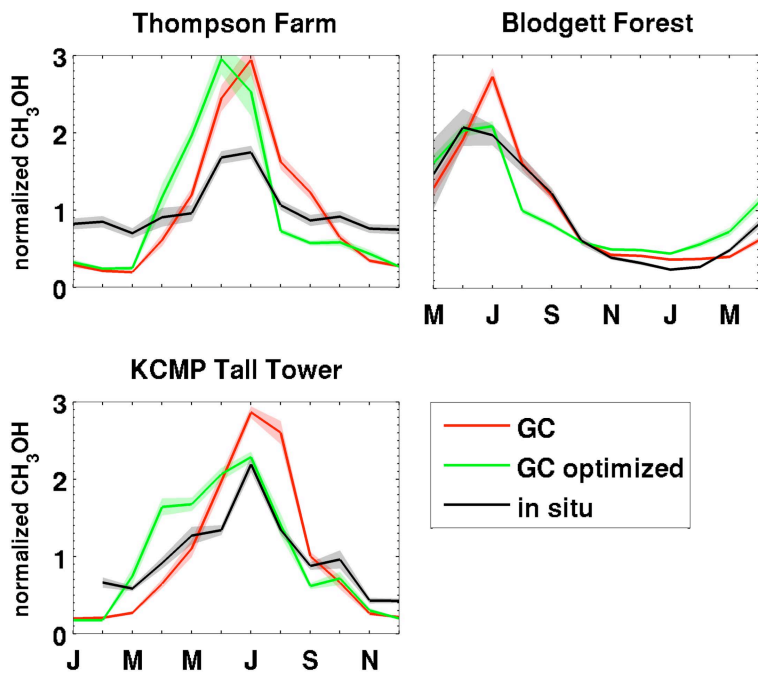

Fig. 10. Seasonal cycle in atmospheric methanol at North American surface sites. Observations from Thompson Farm in $\mathrm{NH}$, USA (January-December 2008), Blodgett Forest in CA, USA (May 2000-April 2001), and the KCMP tall tower in MN, USA (JanuaryDecember 2010), are compared to modeled concentrations from the GEOS-Chem base-case (red) and optimized (green) simulations. Concentrations are normalized to the annual mean in each case. Model results for Blodgett Forest are for 2009 rather than 2000 2001. Lines show the monthly mean values, while shaded areas indicate the standard error about the mean.

IASI. This may partly reflect retrieval uncertainty and reduced sampling statistics during months when methanol concentrations are low.

Figure 10 shows in situ measurements (normalized by the annual mean) from Thompson Farm in New Hampshire $\left(43.11^{\circ} \mathrm{N}, 70.95^{\circ} \mathrm{W}, 24 \mathrm{~m}\right.$ a.s.1.) (Jordan et al., 2009), the Blodgett Forest Research Station in California $\left(38.90^{\circ} \mathrm{N}\right.$, $120.63^{\circ} \mathrm{W}, 1315 \mathrm{~m}$ a.s.1.) (Schade and Goldstein, 2006), and the KCMP tall tower in Minnesota $\left(44.69^{\circ} \mathrm{N}, 93.07^{\circ} \mathrm{W}\right.$, $534 \mathrm{~m}$ a.s.l.) (Hu et al., 2011). The optimized simulation gives a better representation of the timing of the seasonal peak in each case, and reduces the summertime RMSD at the KCMP tall tower and Blodgett Forest. Normalized methanol abundance during spring and summer appears to be too high in the optimized simulation at the KCMP tall tower and at Thompson Farm; this is in part because the model underestimates winter methanol concentrations at both sites, so the seasonal amplitude is overly pronounced. Additionally, local sources of methanol at each site may not be well captured by the $2^{\circ} \times 2.5^{\circ}$ simulation.

Although the optimized simulation yields a seasonal cycle for atmospheric methanol that is more accurate based on midlatitude observations, key discrepancies still exist in terms of the absolute concentrations. Over the western US, simulated column amounts are still a factor of two lower than the IASI observations (Fig. S3 in the Supplement). At Blodgett, absolute surface concentrations in the model are $4-10 \times$ 
lower than observed. This discrepancy could be due to the fact that this particular measurement site is located in an area of complex terrain, but it is also consistent with a missing regional source in the model.

\section{Summary and conclusions}

We evaluated new retrievals of tropospheric methanol from the Tropospheric Emission Spectrometer (TES) and the Infrared Atmospheric Sounding Interferometer (IASI), and used them in conjunction with the GEOS-Chem CTM (driven with MEGAN emissions) to better quantify the seasonality of methanol emissions from terrestrial plants in temperate ecosystems. The TES retrievals show good agreement with aircraft observations for retrievals with DOFS $>0.5$. The TES data exhibit higher concentrations compared to the model than do the IASI data, which may reflect differing vertical sensitivity for the two sensors or the inclusion of retrievals with low DOFS in the IASI data.

A full year of IASI and TES retrievals over midlatitude regions of the Northern Hemisphere revealed a clear seasonal offset in the timing of model emissions, with peak concentrations occurring 1-2 months too late in the model. We applied the satellite data to derive a more robust global constraint on the change in methanol emission rate as a function of leaf age in midlatitude ecosystems. We find that the seasonality in atmospheric methanol as measured by IASI over key midlatitude regions is well-captured using revised relative emissions factors of $11.0,0.26,0.12$, and 3.0 for new, growing, mature, and old leaves, respectively. These parameters represent an increase in emissions for new and old leaves, and a decrease for growing and mature leaves compared to the standard model. Implementing these optimized emission factors in the model, and employing a leaf area index activity factor of 0.5 for expanding canopies with $\mathrm{LAI}<1.2$, leads to a seasonal cycle in atmospheric methanol that is more consistent with the IASI measurements, as well as with independent data from TES. These relative emission factors for the different leaf age classes were derived with respect to midlatitude observations and are not necessarily applicable to the tropics.

While our findings here should enable more accurate simulations of atmospheric methanol in temperate regions of the world, some key issues remain to be resolved. For example, large underestimates in the overall source magnitude still exist in areas such as the western US, pointing to a missing regional source in the model. Based on observations by Geron et al. (2006), it is possible that emissions from desert shrubs are currently underestimated in MEGAN, but this requires further investigation. The contribution of deposition and $\mathrm{OH}$ oxidation to the methanol underestimate also warrants further study. The new global datasets from TES and IASI should provide powerful new constraints for improv- ing present understanding of methanol emissions for different plant functional types.

\section{Supplementary material related to this article is available online at: http://www.atmos-chem-phys.net/12/ 5897/2012/acp-12-5897-2012-supplement.pdf.}

Acknowledgements. This work was supported by NASA through the Atmospheric Chemistry Modeling and Analysis Program (Grant \#NNX10AG65G), by NSF through the Atmospheric Chemistry Program (Grant \#0937004), and also by the University of Minnesota Supercomputing Institute. The constrained linear regression was performed using code developed by Michele Cappellari. We gratefully thank John Worden and Ming Luo for their role in developing the TES methanol retrieval. We thank Alex Guenther for his help and suggestions in refining this work. We also thank Gunnar Schade for providing the Blodgett Forest measurements. IASI has been developed and built under the responsibility of the Centre National d'Études Spatiales (CNES, France). It is flown onboard the MetOp satellites as part of the EUMETSAT Polar System. The IASI level 1 data are distributed in near real time by EUMETSAT through the Eumetcast dissemination system. L. Clarisse is a Postdoctoral Researcher (Chargé de Recherches) and P. F. Coheur is a Research Associate (Chercheur Qualifiée) with F.R.S.-FNRS.

Edited by: L. Ganzeveld

\section{References}

Andreae, M. O. and Merlet, P.: Emission of trace gases and aerosols from biomass burning, Global Biogeochem. Cy., 15, 955-966, doi:10.1029/2000GB001382, 2001.

Apel, E. C., Hills, A. J., Lueb, R., Zindel, S., Eisele, S., and Riemer, D. D.: A fast-GC/MS system to measure C-2 to C-4 carbonyls and methanol aboard aircraft, J. Geophys. Res., 108, 8794, doi:10.1029/2002JD003199, 2003.

Auvray, M. and Bey, I.: Long-range transport to Europe: seasonal variations and implications for the European ozone budget, J. Geophys. Res., 110, D11303, doi:10.1029/2004JD005503, 2005.

Beer, R., Glavich, T. A., and Rider, D. M.: Tropospheric emission spectrometer for the Earth Observing System's Aura Satellite, Appl. Opt., 40, 2356-2367, 2001.

Beer, R., Shephard, M. W., Kulawik, S. S., Clough, S. A., Eldering, A., Bowman, K. W., Sander, S. P., Fisher, B. M., Payne, V. H., Luo, M., Osterman, G. B., and Worden, J. R.: First satellite observations of lower tropospheric ammonia and methanol, Geophys. Res. Lett., 35, L09801, doi:10.1029/2008GL033642, 2008.

Bernath, P. F., McElroy, C. T., Abrams, M. C., Boone, C. D., Butler, M., Camy-Peyret, C., Carleer, M., Clerbaux, C., Coheur, P. F., Decola, P., DeMaziere, M., Drummond, J. R., Dufour, D., Evans, W. F. J., Fast, H., Fussen, D., Gilbert, K., Jennings, D. E., Llewellyn, E. J., Lowe, R. P., Mahieu, E. McConnell, J. C., McHugh, M., McLeod, S. D., Michaud, R., Midwinter, C., Nassar, R., Nichitiu, F., Nowlan, C., Rinsland, C. 
P., Rochon, Y. J., Rowlands, N. A., Walkty, I., Wardle, D. A., Wehrle, V., Zander, R., Zou, J.: Atmospheric Chemistry Experiment (ACE): mission overview, Geophys. Res. Lett., 32, L15S01, doi:10.1029/2005GL022386, 2005.

Bracho-Nunez, A., Welter, S., Staudt, M., and Kesselmeier, J.: Plant-specific volatile organic compound emission rates from young and mature leaves of Mediterranean vegetation, J. Geophys. Res., 116, D16304, doi:10.1029/2010JD015521, 2011.

Brock, C. A., Cozic, J. Bahreini, R., Froyd, K. D., Middlebrook, A. M., McComiskey, A., Brioude, J., Cooper, O. R., Stohl, A., Aiken, K. C., de Gouw, J. A., Fahey, D. W., Farrare, R. A., Gao, R. S., Gore, W., Holloway, J. S., Hubler, G., Jefferson, A., Lack, D. A., Lance, S., Moore, R. H., Murphy, D. M., Nenes, A., Novelli, P. C., Nowak, J. B., Ogren, J. A., Peischl, J., Pierce, R. B., Pilweskie, P., Quinn, P. K., Ryerson, T. B., Schmidt, K. S., Schwarz, J. P., Sodemann, H., Spackman, J. R., Stark, H., Thomson, D. S., Thornberry, T., Veres, P., Watts, L. A., Warneke, C: Characteristics, sources, and transport of aerosols measured in spring 2008 during the Aerosol, Radiation, and Cloud Processes affecting Arctic Climate (ARCPAC) Project, Atmos. Chem. Phys., 11, 2423-2453, doi:10.5194/acp-11-24232011, 2011.

Cady-Pereira, K. E., Shephard, M. W., Millet, D. B., Luo, M., Wells, K. C., Xiao, Y. Payne, V. H., and Worden, J.: Methanol from TES global observations: retrieval algorithm and seasonal and spatial variability, Atmos. Chem. Phys. Discuss., 12, 11823-11859, doi:10.5194/acpd-12-11823-2012, 2012.

Carpenter, L. J., Lewis, A. C., Hopkins, J. R., Read, K. A., Longley, I. D., and Gallagher, M. W.: Uptake of methanol to the North Atlantic Ocean surface, Global Biogeochem. Cy., 18, GB4027, doi:10.1029/2004GB002294, 2004.

Choi, W., Faloona, I. C., Bouvier-Brown, N. C., McKay, M., Goldstein, A. H., Mao, J., Brune, W. H., LaFranchi, B. W., Cohen, R. C., Wolfe, G. M., Thornton, J. A., Sonnenfroh, D. M., and Millet, D. B.: Observations of elevated formaldehyde over a forest canopy suggest missing sources from rapid oxidation of arboreal hydrocarbons, Atmos. Chem. Phys., 10, 8761-8781, doi:10.5194/acp-10-8761-2010, 2010.

Clerbaux, C., Boynard, A., Clarisse, L., George, M., Hadji-Lazaro, J., Herbin, H., Hurtmans, D., Pommier, M., Razavi, A., Turquety, S., Wespes, C., and Coheur, P. F.: Monitoring of atmospheric composition using the thermal infrared IASI/MetOp sounder, Atmos. Chem. Phys., 9, 6041-6054, doi:10.5194/acp-9-6041-2009, 2009.

Clough, S. A., Shephard, M. W., Worden, J., Brown, P. D., Worden, H. M., Luo, M., Rodgers, C. D., Rinsland, C. P., Goldman, A., Brown, L., Kulawik, S. S., Eldering, A., Lampel, M., Osterman, G., Beer, R., Bowman, K., Cady-Pereira, K. E., and Mlawer, E. J.: Forward model and Jacobians for Tropospheric Emission Spectrometer retrievals, IEEE Trans. Geosci. Remote Sens., 44, 1308-1323, 2006.

Coheur, P. F., Clarisse, L., Turquety, S., Hurtmans, D., and Clerbaux, C.: IASI measurements of reactive trace species in biomass burning plumes, Atmos. Chem. Phys., 9, 5655-5667, doi:10.5194/acp-9-5655-2009, 2009.

Custer, T. G. and Schade, G. W.: Seasonal OVOC fluxes from an agricultural field planted with sugar beet, Eos Trans. AGU, 86, Fall Meet. Suppl., Abstract A51B-0060, San Francisco, USA, 2005. de Gouw, J. A., Middlebrook, A. M., Warneke, C., Goldan, P. D., Kuster, W. C., Roberts, J. M., Fehsenfeld, F. C., Worsnop, D. R., Canagaratna, M. R., Pszenny, A. A. P., Keene, W. C., Marchewka, M., Bertman, S. B., and Bates, T. S.: Budget of organic carbon in a polluted atmosphere: results from the New England Air Quality Study in 2002, J. Geophys. Res., 110, D16305, doi:10.1029/2004JD005623, 2005.

de Gouw, J. and Warneke, C.: Measurements of volatile organic compounds in the Earth's atmosphere using proton-transferreaction mass spectrometry, Mass Spectrom. Rev., 26, 223-257, 2007.

Dufour, G., Boone, C. D., Rinsland, C. P., and Bernath, P. F.: First space-borne measurements of methanol inside aged southern tropical to mid-latitude biomass burning plumes using the ACE-FTS instrument, Atmos. Chem. Phys., 6, 3463-3470, doi:10.5194/acp-6-3463-2006, 2006.

Dufour, G., Szopa, S., Hauglustaine, D. A., Boone, C. D., Rinsland, C. P., and Bernath, P. F.: The influence of biogenic emissions on upper-tropospheric methanol as revealed from space, Atmos. Chem. Phys., 7, 6119-6129, doi:10.5194/acp-7-61192007, 2007.

Duncan, B. N., Logan, J. A., Bey, I., Megretskaia, I. A., Yantosca, R. M., Novelli, P. C., Jones, N. B., Rinsland, C. P.: Global budget of CO, 1988-1997: source estimates and validation with a global model, J. Geophys. Res., 112, D22301, doi:10.1029/2007JD008459, 2007.

Galbally, I. E. and Kirstine, W.: The production of methanol by flowering plants and the global cycle of methanol, J. Atmos. Chem., 43, 195-229, 2002.

Geron, C., Guenther, A., Greenberg, J., Karl, T., and Rasmussen, R.: Biogenic volatile organic compound emissions from desert vegetation of the southwestern US, Atmos. Environ., 40, 16451660, 2006.

Goldan, P. D., Trainer, M., Kuster, W. C., Parrish, D. D., Carpenter, J., Roberts, J. M., Yee, J. E., and Fehsenfeld, F. C.: Measurements of hydrocarbons, oxygenated hydrocarbons, carbon monoxide, and nitrogen oxides in an urban basin in Colorado: implications for emission inventories, J. Geophys. Res., 100, 22771-22783, 1995.

Guenther, A., Karl, T., Harley, P., Wiedinmyer, C., Palmer, P. I., and Geron, C.: Estimates of global terrestrial isoprene emissions using MEGAN (Model of Emissions of Gases and Aerosols from Nature), Atmos. Chem. Phys., 6, 3181-3210, doi:10.5194/acp-63181-2006, 2006.

Harley, P., Greenberg, J., Niinemets, U., and Guenther, A.: Environmental controls over methanol emission from leaves, Biogeosciences, 4, 1083-1099, doi:10.5194/bg-4-1083-2007, 2007.

Heikes, B. G., Chang, W. N., Pilson, M. E. Q., Swift, E., Singh, H. B, Guenther, A., Jacob, D. J., Field, B. D., Fall, R., Riemer, D., and Brand, L.: Atmospheric methanol budget and ocean implication, Global Biogeochem. Cy., 16, 1133, doi:10.1029/2002GB001895, 2002.

Holzinger, R., Warneke, C., Hansel, A., Jordan, A., Lindinger, W., Scharffe, D. H., Schade, G., and Crutzen, P. J.: Biomass burning as a source of formaldehyde, acetaldehyde, methanol, acetone, acetonitrile, and hydrogen cyanide, Geophys. Res. Lett., 26, 1161-1164, 1999.

Holzinger, R., Jordan, A., Hansel, A. and Lindinger, W.: Methanol measurements in the lower atmosphere near Innsbruck (047 de- 
grees $16^{\prime} \mathrm{N}$; 011 degrees 24' E), Austria, Atmos. Environ., 35, 2525-2532, 2001.

Hu, L., Millet, D. B., Mohr, M. J., Wells, K. C., Griffis, T. J., and Helmig, D.: Sources and seasonality of atmospheric methanol based on tall tower measurements in the US Upper Midwest, Atmos. Chem. Phys., 11, 11145-11156, doi:10.5194/acp-1111145-2011, 2011.

Hudman, R. C., Jacob, D. J., Turquety, S., Leibensperger, E. M., Murray, L. T., Wu, S., Gilliland, A. B., Avery, M., Bertram, T. H., Brune, W., Cohen, R. C., Dibb, J. E., Flocke, F. M., Fried, A., Holloway, J., Neuman, J. A., Orville, R., Perring, A., Ren, X., Sachse, G. W., Singh, H. B., Swanson, A., Wooldridge, P. J.: Surface and lightning sources of nitrogen oxides over the United States: magnitudes, chemical evolution, and outflow, J. Geophys. Res., 112, D12S05, doi:10.1029/2006JD007912, 2007.

Hudman, R. C., Murray, L. T., Jacob, D. J., Millet, D. B., Turquety, S., Wu, S., Blake, D. R., Goldstein, A. H., Holloway, J., and Sachse, G. W.: Biogenic versus anthropogenic sources of CO in the United States, Geophys. Res. Lett., 35, L04801, doi:10.1029/2007GL032393, 2008.

Hüve, K., Christ, M., Kleist, E., Uerlings, R., Niinemets, U., Walter, A., and Wildt, J: Simultaneous growth and emission measurements demonstrate an interactive control of methanol release by leaf expansion and stomata, J. Exp. Bot., 58, 1783-1793, 2007.

Jacob, D. J., Field, B. D., Li, Q. B., Blake, D. R., de Gouw, J., Warneke, C., Hansel, A., Wisthaler, A., Singh, H. B., Guenther, A.: Global budget of methanol: constraints from atmospheric observations, J. Geophys. Res., 110, D08303, doi:10.1029/2004JD005172, 2005.

Jacob, D. J., Crawford, J. H., Maring, H., Clarke, A. D., Dibb, J. E., Emmons, L. K., Ferrare, R. A., Hostetler, C. A., Russell, P. B., Singh, H. B., Thompson, A. M., Shaw, G. E., McCauley, E., Pederson, J. R., Fisher, J. A.: The Arctic Research of the Composition of the Troposphere from Aircraft and Satellites (ARCTAS) mission: design, execution, and first results, Atmos. Chem. Phys., 10, 5191-5212, doi:10.5194/acp-10-5191-2010, 2010.

Jordan, C., Fitz, E., Hagan, T., Sive, B., Frinak, E., Haase, K., Cottrell, L., Buckley, S., Talbot, R.: Long-term study of VOCs measured with PTR-MS at a rural site in New Hampshire with urban influences, Atmos. Chem. Phys., 9, 4677-4697, doi:10.5194/acp9-4677-2009, 2009.

Karl, T., Guenther, A., Spirig, C., Hansel, A., and Fall, R.: Seasonal variation of biogenic VOC emissions above a mixed hardwood forest in northern Michigan, Geophys. Res. Lett., 30, 2186, doi:10.1029/2003GL018432, 2003.

Karl, T., Harren, F., Warneke, C., de Gouw, J., Grayless, C., and Fall, R.: Senescing grass crops as regional sources of reactive volatile organic compounds, J. Geophys. Res., 110, D15302, doi:10.1029/2005JD005777, 2005.

Karl, T., Harley, P., Emmons, L., Thornton, B., Guenther, A., Basu, C., Turnipseed, A., and Jardine, K.: Efficient atmospheric cleansing of oxidized organic trace gases by vegetation, Science, 330, 816-819, doi:10.1126/science.1192534, 2010.

Kleb, M. M., Chen, G., Crawford, J. H., Flocke, F. M., and Brown, C. C.: An overview of measurement comparisons from the INTEX-B/MILAGRO airborne field campaign, Atmos. Meas. Tech., 4, 9-27, doi:10.5194/amt-4-9-2011, 2011.

Kuhns, H., Green, M., and Etyemezian, V.: Big Bend Regional Aerosol and Visibility Observational (BRAVO) Study Emis- sions Inventory, Report prepared for BRAVO steering committee, Desert Research Institute, Las Vegas, Nevada, USA, 2003.

Lappalainen, H. K., Sevanto, S., Bäck, J., Ruuskanen, T. M., Kolari, P., Taipale, R., Rinne, J., Kulmala, M., and Hari, P.: Daytime concentrations of biogenic volatile organic compounds in a boreal forest canopy and their relation to environmental and biological factors, Atmos. Chem. Phys., 9, 5447-5459, doi:10.5194/acp-9-5447-2009, 2009.

Macdonald, R. C. and Fall, R.: Detection of substantial emissions of methanol from plants to the atmosphere, Atmos. Environ., 27, 1709-1713, 1993.

Millet, D. B., Donahue, N. M., Pandis, S. N., Polidori, A., Stanier, C. O., Turpin, B. J., and Goldstein, A. H.: Atmospheric volatile organic compound measurements during the Pittsburgh Air Quality Study: results, interpretation, and quantification of primary and secondary contributions, J. Geophys. Res., 110, D07S07, doi:10.1029/2004JD004601, 2005.

Millet, D. B., Jacob, D. J., Turquety, S., Hudman, R. C., Wu, S., Fried, A., Walega, J., Heikes, B. G., Blake, D. R., Singh, H. B., Anderson, B. E., and Clarke, A. D.: Formaldehyde distribution over North America: implications for satellite retrievals of formaldehyde columns and isoprene emission, J. Geophys. Res., 111, D24S02, doi:10.1029/2005JD006853, 2006.

Millet, D. B., Jacob, D. J., Custer, T. G., de Gouw, J. A., Goldstein, A. H., Karl, T., Singh, H. B., Sive, B. C., Talbot, R. W., Warneke, C., and Williams, J.: New constraints on terrestrial and oceanic sources of atmospheric methanol, Atmos. Chem. Phys., 8, 68876905, doi:10.5194/acp-8-6887-2008, 2008.

Nemecek-Marshall, M., Macdonald, R. C., Franzen, F. J., Wojciechowski, C. L., and Fall, R.: Methanol emission from leaves: enzymatic detection of gas-phase methanol and relation of methanol fluxes to stomatal conductance and leaf development, Plant Physiol., 108, 1359-1368, 1995.

Olson, D. M., Dinerstein, E., Wikramanayake, E. D., Burgess, N. D., Powell, G. V. N., Underwood, E. C., D’Amico, J. A., Itoua, I., Strand, H. E., Morrison, J. C., Loucks, C. J., Allnutt, T. F., Ricketts, T. H., Kura, Y., Lamoreux, J. F., Wettengel, W. W., Hedao, P., and Kassem, K. R.: Terrestrial ecoregions of the world: A new map of life on Earth, Bioscience, 51, 933-938, 2001.

Parrish, D. D., Allen, D. T., Bates, T. S., Estes, M., Fehsenfeld, F. C., Feingold, G., Ferrare, R., Hardesty, R. M., Meagher, J. F., Nielsen-Gammon, J. W., Pierce, R. B., Ryerson, T. B., Seinfeld, J. H., Williams, E. J.: Overview of the Second Texas Air Quality Study (TexAQS II) and the Gulf of Mexico Atmospheric Composition and Climate Study (GoMACCS), J. Geophys. Res., 114, D00F13, doi:10.1029/2009JD011842, 2009.

Payne, V. H., Clough, S. A., Shephard, M. W., Nassar, R., and Logan, J. A.: Information-centered representation of retrievals with limited degrees of freedom for signal: application to methane from the Tropospheric Emission Spectrometer, J. Geophys. Res., 114, D10307, doi:10.1029/2008JD010155, 2009.

Razavi, A., Karagulian, F., Clarisse, L., Hurtmans, D., Coheur, P. F., Clerbaux, C., Muller, J. F., and Stavrakou, T.: Global distributions of methanol and formic acid retrieved for the first time from the IASI/MetOp thermal infrared sounder, Atmos. Chem. Phys., 11, 857-872, doi:10.5194/acp-11-857-2011, 2011.

Rodgers, C. D.: Inverse Methods for Atmospheric Sounding: Theory and Practice, World Scientific, Tokyo, Japan, 2000. 
Schade, G. W. and Custer, T. G.: OVOC emissions from agricultural soil in northern Germany during the 2003 European heat wave, Atmos. Environ., 38, 6105-6114, doi:10.1016/j.atmosenv.2004.08.017, 2004.

Schade, G. W. and Goldstein, A. H.: Seasonal measurements of acetone and methanol: abundances and implications for atmospheric budgets, Global Biogeochem. Cy., 20, GB1011, doi:10.1029/2005GB002566, 2006.

Shephard, M. W., Cady-Pereira, K. E., Luo, M., Henze, D. K., Pinder, R. W., Walker, J. T., Rinsland, C. P., Bash, J. O., Zhu, L., Payne, V. H., and Clarisse, L.: TES ammonia retrieval strategy and global observations of the spatial and seasonal variability of ammonia, Atmos. Chem. Phys., 11, 10743-10763, doi:10.5194/acp-11-10743-2011, 2011.

Singh, H. B, Chen, Y., Staudt, A., Jacob, D., Blake, D., Heikes, B., and Snow, J.: Evidence from the Pacific troposphere for large global sources of oxygenated organic compounds, Nature, 410, 1078-1081, 2001.

Singh, H. B., Salas, L. J., Chatfield, R. B., Czech, E., Fried, A., Walega, J., Evans, M. J., Field, B. D., Jacob, D. J., Blake, D., Heikes, B., Talbot, R., Sachse, G., Crawford, J. H., Avery, M. A., Sandholm, S., and Fuelberg, H.: Analysis of the atmospheric distribution, sources, and sinks of oxygenated volatile organic chemicals based on measurements over the Pacific during TRACE-P, J. Geophys. Res., 109, D15S07, doi:10.1029/2003JD003883, 2004.

Singh, H. B., Brune, W. H., Crawford, J. H., Flocke, F., and Jacob, D. J.: Chemistry and transport of pollution over the Gulf of Mexico and the Pacific: spring 2006 INTEX-B campaign overview and first results, Atmos. Chem. Phys., 9, 2301-2318, doi:10.5194/acp-9-2301-2009, 2009.

Stavrakou, T., Mueller, J. F., De Smedt, I., Van Roozendael, M., van der Werf, G. R., Giglio, L., and Guenther, A.: Global emissions of non-methane hydrocarbons deduced from SCIAMACHY formaldehyde columns through 2003-2006, Atmos. Chem. Phys., 9, 3663-3679, doi:10.5194/acp-9-3663-2009, 2009.

Stavrakou, T., Guenther, A., Razavi, A., Clarisse, L., Clerbaux, C., Coheur, P. F., Hurtmans, D., Karagulian, F., De Maziere, M., Vigouroux, C., Amelynck, C., Schoon, N., Laffineur, Q., Heinesch, B., Aubinet, M., Rinsland, C., and Muller, J. F.: First space-based derivation of the global atmospheric methanol emission fluxes, Atmos. Chem. Phys., 11, 4873-4898, doi:10.5194/acp-11-4873-2011, 2011.

Tie, X., Guenther, A., and Holland, E.: Biogenic methanol and its impacts on tropospheric oxidants, Geophys. Res. Lett., 30, 1881, doi:10.1029/2003GL017167, 2003.
Tyndall, G. S., Cox, R. A., Granier, C., Lesclaux, R., Moortgat, G. K., Pilling, M. J., Ravishankara, A. R., and Wallington, T. J.: Atmospheric chemistry of small organic peroxy radicals, J. Geophys. Res., 106, 12157-12182, 2001.

van der Werf, G., Randerson, J., Giglio, L., Collatz, G., Kasibhatla, P., and Arellano, A.: Interannual variability in global biomass burning emissions from 1997 to 2004, Atmos. Chem. Phys., 6, 3423-3441, doi:10.5194/acp-6-3423-2006, 2006.

Vestreng, V. and Klein, H.: Emission data reported to UNECE/EMEP: Quality assurance \& presentation of WebDab, Norweigian Meterological Institute, Oslo, Norway, MSC-W Status Report, 2002.

Warneke, C., Karl, T., Judmaier, H., Hansel, A., Jordan, A., Lindinger, W., and Crutzen, P. J.: Acetone, methanol, and other partially oxidized volatile organic emissions from dead plant matter by abiological processes: significance for atmospheric $\mathrm{HO}_{\mathrm{x}}$ chemistry, Global Biogeochem. Cy., 13, 9-17, doi:10.1029/98GB02428, 1999.

Warneke, C., McKeen, S. A., de Gouw, J. A., Goldan, P. D., Kuster, W. C., Holloway, J. S., Williams, E. J., Lerner, B. M., Parrish, D. D., Trainer, M., Fehsenfeld, F. C., Kato, S., Atlas, E. L., Baker, A., and Blake, D. R.: Determination of urban volatile organic compound emission ratios and comparison with an emissions database, J. Geophys. Res., 112, D10S47, doi:10.1029/2006JD007930, 2007.

Williams, J., Holzinger, R., Gros, V., Xu, X., Atlas, E., and Wallace, D. W. R.: Measurements of organic species in air and seawater from the tropical Atlantic, Geophys. Res. Lett., 31, L23S06, doi:10.1029/2004GL020012, 2004.

Xiao, Y., Cady-Pereira, K. E., Payne, V. H., Millet, D. B., Shephard, M. W., Luo, M., Alvarado, M., Wells, K. C., Apel, E. C., Campos, T. L., Singh, H. B., and Sachse, G. W.: Methanol-CO correlations in Mexico City pollution outflow from aircraft and satellite during MILAGRO, Atmos. Chem. Phys. Discuss., 12, 5705-5738, doi:10.5194/acpd-12-5705-2012, 2012.

Yang, W., Shabanov, N. V., Huang, D., Wang, W., Dickinson, R. E., Nemani, R. R., Knyazikhin, Y., and Myneni, R. B.: Analysis of leaf area index products from combination of MODIS Terra and Aqua data, Remote Sens. of Environ., 104, 297-312, 2006.

Zhang, Q., Streets, D. G., Carmichael, G. R., He, K. B., Huo, H., Kannari, A., Klimont, Z., Park, I. S., Reddy, S., Fu, J. S., Chen, D., Duan, L., Lei, Y., Wang, L. T., and Yao, Z. L.: Asian emissions in 2006 for the NASA INTEX-B mission, Atmos. Chem. Phys., 9, 5131-5153, doi:10.5194/acp-9-5131-2009, 2009. 